\title{
BREVE ESPAÇO ENTRE COR E SOMBRA - Cristóvão Tezza Breve espaço entre o autor-criador e o autor como mecanismo discursivo: o valor do autor na História
}

\author{
Juliana da Silva Passos ${ }^{1}$
}

Que importa quem fala?

Samuel Beckett

O que você faria com uma escultura de Modigliani nas suas mãos? Assim, original e nas suas mãos? Agora, suponhamos que a escultura fosse falsa? Diga-me: o que você faria? Pois este foi o dilema de Tato Simmone há uma ou duas semanas atrás: uma escultura, nem falsa, nem verdadeira (ou falsa e verdadeira) nas mãos dele. Roubada, mas nas mãos dele. E o que fez o deslocado herói pós-moderno e fragmentado que protagoniza Breve espaço entre cor e sombra de Cristóvão Tezza? Bem, ele ficou com ela, afinal, ela era bonita... E na certeza da (não) originalidade da obra, seria diferente? Se a função da arte é provocar o prazer estético, e a escultura provocava, o que importa a autoria da obra então?

Em vez de responder "Sendo assim, não importa!" ou "Importa, pois foi o autor que fez a obra”, procuremos possíveis respostas na história, pois lá encontraremos inúmeros sujeitos que há tempos têm se esforçado para responder a pergunta que nos fazemos agora.

Desde biblicamente muitos anos atrás, segundo Foucault (2006), a crítica por vários séculos derivou de uma mesma fórmula para definir o autor. São Jerônimo, bem anterior a Chico Buarque com seu Budapeste ou Rubem Fonseca com os contos Agruras de um jovem escritor ou Artes e Ofícios, obras que através da figura do ghost-writer, ou seja, pessoas que, profissionalmente ou não, escrevem no lugar do outro a quem a obra será publicamente atribuída, já explicava que a homonímia não bastava para identificar o criador da obra, afinal, indivíduos diferentes poderiam utilizar-se do mesmo nome (E Homero? Será um, três, ou sabe lá quantos?), ou até mesmo assumir a identidade de outro. Para identificar a originalidade da obra, São Jerônimo nos fornece quatro critérios (FOUCAULT, 2006, p. 277-278). Vamos a eles, conferir se São Jerônimo conseguiria descobrir os autores destas obras fictícias da literatura brasileira contemporânea:

1) Se entre as várias obras atribuídas a um autor, uma é inferior às outras, tiremos esta da lista. Este critério não funcionaria com os obra do ghost-writers de

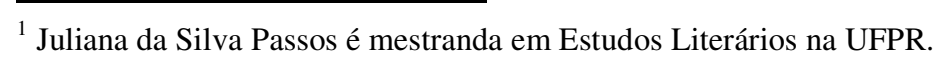


Budapeste, assim como para a de Artes e Ofícios, uma vez que são elas obras únicas atribuídas a seus supostos autores. No caso da escultura, este critério ainda não seria o bastante para revelar a autoria da obra.

2) Se a obra está em contradição com a "doutrina" (acho que o santo pensou em uma certa coerência que permeasse o total da obra) do autor, igualmente a exclua. Idem item número 1.

3) Obras “diferentes", com traços estilísticos não usuais na obra do autor, exclua na hora! Esse item também não acrescenta muito. Continuamos na mesma.

4) Nos casos da obra literária, observe os acontecimentos históricos, os fatos e certifique-se de que não há nada posterior à vida do suposto criador. Se houver, já sabe. Este item também não nos ajuda muito, uma vez que os ghost-writers eram contemporâneos dos supostos criadores.

Para São Jerônimo a identificação do criador da obra era realmente algo muito importante, o que é uma pena, já que, de acordo com o nosso teste, os métodos de identificação de autoria dele não eram lá muito eficazes. Bem, e se para ele, que afinal de contas era um Santo, isso já não era fácil, quem dirá para todos os outros simples mortais, sem vocações divinas. Isto nos leva a pensar que a identificação da autoria (no sentido de criação) beira o impossível. E na eterna impossibilidade de se descobrir algo, de que adianta discutir? É como a traição de Capitu.

De lá pra cá, até o século XIX, qualquer sujeito com bom senso nos diria que saber quem é o autor é fundamental, afinal de contas, quem melhor do que ele para revelar ao público o que a sua obra queria dizer? Estes foram tempos de glória para o autor, que dizia e desdizia o que queria ou o que não queria transmitir com a sua própria obra. Podia não ganhar muito, ser visto como um excêntrico, ser marginalizado, incompreendido, mas isto ninguém tirava do pobre: ele era o detentor máximo do significado da obra. Grandes tempos para os autores aquele. Pois daí por diante, cada vez mais o autor manda menos, ou melhor, não manda, ao menos quando pensamos no "significado" da obra.

Começou no início do século XX. Primeiro foram os russos, querendo transformar tudo em ciência (e por ciência entenda-se ciência exata)! E se o estudo da literatura quer tornar-se uma ciência, ele deve reconhecer o "processo" como seu único herói (JAKOBSON, 1921 in: SCHAIDERMAN, 1976 in: BONNICI \& ZOLLIN, 2003). Ela [a obra literária] poderia conter esta ou aquela filosofia, refletir esta ou aquela opinião política, mas, do ponto de vista do estudo literário, o que importava era o priom, ou o processo, isto é, o princípio da organização da obra como produto estético, jamais uma fator externo 
(SCHNAIDERMAN, 1976). Sendo o autor um fator externo, fica decretada a "morte do autor", que não é mais o detentor, o dono do significado. O leitor, que nunca havia sido dono de nada mesmo (a não ser do seu próprio livro, quando este não era da biblioteca) continua como está. Quem manda agora é o texto em sua materialidade, as estruturas pertencentes à linguagem. O autor é apenas o criador, aquele que utiliza-se de determinados "processos de singularização" (a tal "desautomatização da linguagem") para criar o efeito de estranhamento que caracterizaria a Literatura. Pouco tempo depois aparece o New Criticism, movimento literário que aparece nos sul dos Estados Unidos entre as décadas de 1920 e 1930 e com as mesmas idéias em relação ao significado - é a "morte do autor" na América. Chocado? Pois saiba que um plano sórdido contra o autor já vinha sendo tramado com o suíço pai do velho e resistente estruturalismo Ferdinand Saussere ainda antes, no princípio do século. O plano porém só veio a se materializar com o "Estruturalismo Literário", a partir da década de 1950 com Todorov, Bremond e Barthes. Todos cientificistas, analisando as estruturas da linguagem, chutando o pobre cadáver do autor como se este fosse um boneco de "Judas" em Quinta-feira Santa, e falando "Fica Tato! Pega esta cabeça! Não faz a menor diferença quem é o autor!”. E depois disso não teve mais espaço para ele (o autor, não Tato!). Veio a Estética da Recepção (que considera o autor como o produtor do texto, porém não detentor do sentido), depois os pós-estruturalistas (o autor não é mais nem mesmo o criador, apenas uma encruzilhada de linguagem composta por citações, repetições e referências), e a atenção passa para o leitor e para a interação dele com o texto. $\mathrm{O}$ único texto existente é aquele que acontece na mente de cada leitor a partir desta interação (e é por isso que, lá em cima, disse que Tato estava com a escultura há uma ou duas semanas atrás). Resumindo, nas palavras de EAGLETON (2003), "poderíamos periodizar a história da moderna teoria literária em três fases: uma preocupação com o autor (Romantismo e séc. XIX); uma preocupação exclusiva com o texto (Nova Crítica) e uma acentuada transferência da atenção para o leitor, nos últimos anos".

Seria esta a resposta do séc. XX? Dane-se o autor? Bem, não é bem assim, pois se assim o fosse já teríamos retornado àqueles tempos remotos quando os animais falavam e “textos que hoje chamaríamos 'literários' (narrativas, contos, epopéias, tragédias, comédias) eram aceitos, postos em circulação, valorizados sem que fosse colocada a questão do seu autor; o anonimato não constituía dificuldade" (FOUCAULT, 2006). E não é isto que acontece, como podemos perceber por nosso próprio comportamento de pessoas que legitimam a arte: compramos fotocópias de novos poetas nas ruas ou o novo romance do Chico Buarque? Professores de poesia contemporânea indicam aos seus alunos a leitura de 
Vinícius ou Plá (sabem de quem eu estou falando?)? Compramos obras de autores desconhecidos ou até mesmo um exemplar em que não conste o nome do autor na capa?

E então? Importa ou não importa a autoria da obra? Eu diria que depende. Quando pensamos no significado da obra, é certo que não. Quando se trata de autor-criador, realizador da obra, também não. Suponhamos que este texto seja um trabalho acadêmico. Suponhamos agora que quem o escreveu, quem realmente passou horas digitando no computador, foi um ghost-writer, e não eu, ou melhor, a pessoa que seria avaliada pelo trabalho? Importa? Tanto quanto a traição de Capitu. Mas quando o autor é o status de autor, aí sim faz muita diferença quem ele é ou deixa de ser. Se a escultura de Tato fosse legitimada como um original Modigliani, faria muita diferença: primeiro, a trama seria pobre. Segundo, Tato não decidiria apenas entre ficar ou não com uma estatua bonita: haveriam muitos interesses e muito dinheiro envolvido. E eu não disse "se a cabeça tivesse sido feita por Modigliani”, mas se tivesse sido aceita como tal, se tivesse sido legitimada como original pelos homens da arte. Não sabemos quem de fato executa as obras, e não temos de fato como saber, portanto isto não nos diz respeito, a não ser como mera especulação. Porém somos nós, público das artes, juntamente com a mídia, que legitimamos quem é, não apenas o criador da obra a ele atribuída, mas principalmente, o Autor. Não meramente um escritor, um escultor, ou um pintor, mas aquele a quem é conferido o estatuto de Autor, e este estatuto sim, faz muita diferença naquilo que "consumimos" (ou não), no mercado, na imprensa, na economia e no mundo da arte.

\section{REFERÊNCIAS}

TEZZA, C. Breve Espaço entre cor e sombra. Rio de Janeiro: Rocco, 1998.

BUARQUE, C. Budapeste. São Paulo: Companhia das Letras, 2003.

FONSECA, R. Agruras de um jovem escritor. In: Contos Reunidos. São Paulo: Companhia das Letras, 1994.

FONSECA, R. Artes e Ofícios In: . O Buraco na Parede. São Paulo: Companhia das Letras, 1995.

BONNICI, T. \& ZOLIN, L.O. (orgs.) Teoria Literária: Abordagens históricas e tendências contemporâneas. Maringá: Eduem, 2003.

EAGLETON, T. Teoria da Literatura: uma introdução. São Paulo: Martins Fontes, 2003. 
FOUCAULT, M. O que é um autor. In: Estética: Literatura e pintura, música e cinema. Rio de Janeiro: Forense Universitária, 2001. p. 264-298.

FOUCAULT, M. A ordem do discurso. São Paulo: Loyola, 2002. 